\title{
Company pushes broad-ranging patent claim
}

The nuclear factor- $\kappa \mathrm{B}(\mathrm{NF}-\kappa \mathrm{B})$ family of transcription factors is involved a broad range of signal transduction pathways and thus a wide array of disease processes-hence its attractiveness as a drug-development target. Given its role in almost every aspect of cell regulation, close attention is being paid to a new legal case brought by Massachusetts-based Ariad Pharmaceuticals, Harvard University and the Whitehead Institute in Boston, in which they claim to have a patent covering "all future inventions that will be made or discovered that operate on the biological principle" of the NF-кB pathway.

As with all patents, the asser-

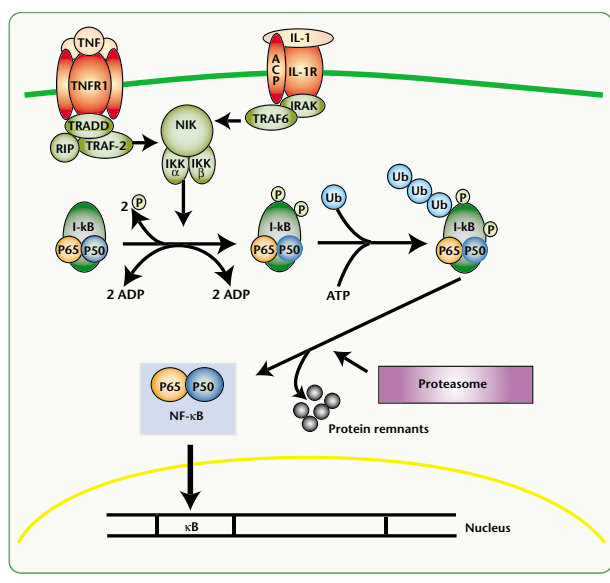

NF- $\mathrm{KB}$ signal transduction pathway. toimmune, inflammatory and cardiovascular diseases. Over the past 15 years, nearly 9,000 journal articles in the PubMed database cite NF- $\kappa \mathrm{B}$, as do almost 400 patents. So, in addition to suing Lilly, Ariad has also sent a letter to 50 unnamed researchers and companies, reportedly alleging patent infringement. Representatives for two companies doing research on NF-кB, Millennium and Isis, confirm that they have received such a letter. Both say they do not believe they are infringing on the patent. According to a statement issued by Millennium, Ariad's complaint conthe other groups is a broad one. It claims the right to methods "for inhibiting expression, in a eukaryotic cell, of a gene whose transcription is regulated by NF$\kappa \mathrm{B} . . . "$ and goes on to claim 202 other research and therapeutic approaches involving the pathway.

In the first instance, Ariad (the lead plaintiff) has filed a lawsuit charging that two of pharmaceutical giant Eli Lilly's drugs-Evista, a selective estrogen-receptor modulator used to treat bone loss, and Xigris, a treatment for sepsis-work on pathway's covered by the patent. Ariad says it sought to negotiate a licensing agreement with Lilly but the company ignored these efforts. Lilly, in its motion to dismiss the case, claims that its "own patents described the medicinal use of both of these drugs long before the (Ariad) patent was sought." Therefore, they state, Ariad has no claim.

If Ariad wins the case, it could allow them to demand licensing fees on existing products as well as a broad range of basic research techniques. For example, $\mathrm{NF}-\kappa \mathrm{B}$ is linked to increased cancer-cell resistance to radiation and chemotherapy, suggesting that an NF- $\mathrm{B}$ inhibitor could improve the effectiveness of cancer treatments.

Held in an inactive state in the cell's cytoplasm, NF- $\kappa \mathrm{B}$ is also involved in au-
June 25, 2002 are valid or cover the use of Velcade," says the statement.

Three academic scientists, David Baltimore, who was at the Whitehead at the time of the patent filing, Philip Sharp at MIT, and Tom Maniatis at Harvard, are credited with discovering the NF- $\kappa \mathrm{B}$ pathway. They licensed the discovery to Ariad. Baltimore and Sharp have declined comment on the case. Ariad says it will not seek royalties from academic researchers, but as Sheldon Krimsky, a professor of Urban Studies at Tufts University, points out, that distinction is not always so clear, since so many university labs now have corporate sponsors. Just how far the patent will reach will be decided by the courts. Ariad estimates that their patent may apply to "many currently marketed drugs ... [that] have markets of several billion dollars annually."

Such a case worries Debra Leonard, director of the Molecular Pathology Laboratory at the University of Pennsylvania School of Medicine. She has spoken out against patents on the use of diagnostic tests for disease genes. Some of the same issues may well apply here, she said. "To me it's not good to have one person controlling an entire area of science," she says. "If you patent the entire pathway that's what you'd be doing."

Tinker Ready, Boston

\section{Video complicates stem-cell debate}

Having established a ban on human cloning as part of its 'Research Involving Embryos and Prohibition of Human Cloning Bill of 2002," the Australian government has now turned its attention to legislation regarding embryonic stem (ES)-cell therapeutic research. However, in trying to present a clear and comprehensible argument in favor of this line of study to members

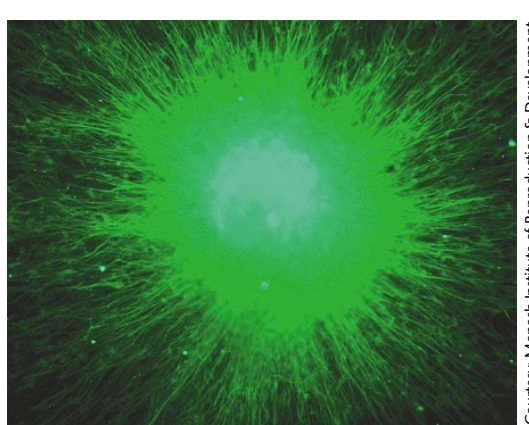

Embryonic stem cell stained with antibody to neural precursor protein. groups that won a competitive bid for AUS $\$ 43.5$ million (US $\$ 23.7$ million) to become Australia's first Bioto become Australia's first Bioter of Excellence. Trounson has led the country's campaign to legalize embryo research. On 26 August, he showed a video to a small group of parliamentarians based on the work of Johns Hopkins Medical School neurologist, Doug Kerr (see box), which deof parliament, the country's leading stem-cell scientist, Alan Trounson, appears to have inadvertently muddied the waters.

Trounson is the CEO of Australia's new Center for Stem Cells and Tissue Repair, a consortium of 12 research picted a rat crippled by a sindbis virus. Twelve weeks after being injected with embryonic germ stem cells, obtained from John Gearhart also at Johns Hopkins, the rat was able to walk again. However, Trounson referred to the grafted cells as ES cells rather than em- 